Section Editor

John J. Millichap, MD

Daniel R. Gold, DO

Correspondence to

Dr. Gold:

Dgold7@jhmi.edu
Supplemental data at Neurology.org

Download teaching slides: Neurology.org

\title{
Teaching NeuroImages: \\ Ocular neuromyotonia
}

An underrecognized cause of transient diplopia

Figure 1 Tonic left inferior rectus contraction causing diplopia in ocular neuromyotonia
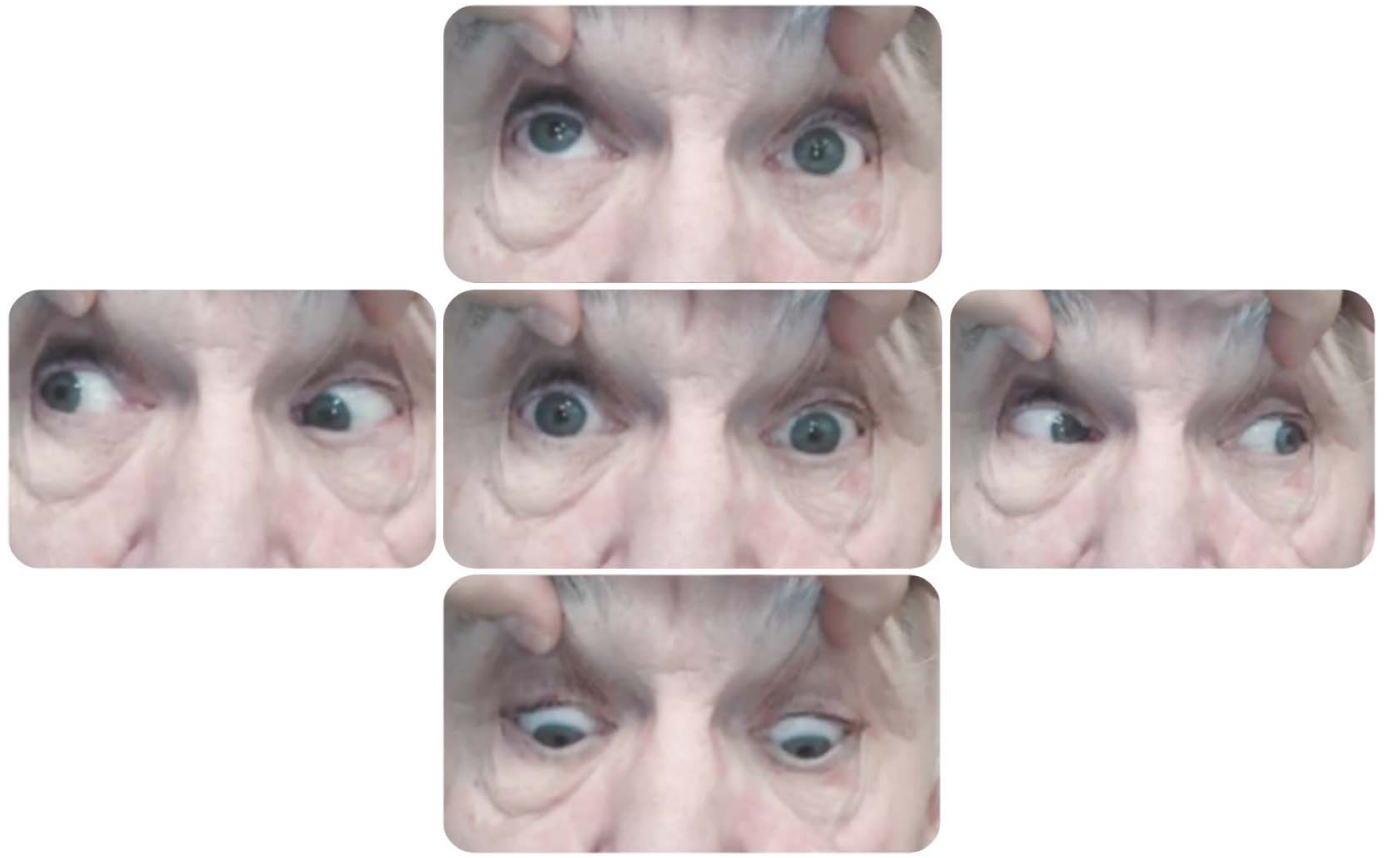

Right hypertropia in primary and eccentric gaze (aside from downgaze), maximal in right and upgaze with a left supraduction deficit.

A 63-year-old man presented with several months of intermittent vertical diplopia mainly while reading. He consistently developed a transient right hypertropia (with left supraduction deficit) after looking down for approximately 10 seconds and then back to primary (figure 1). Neurovascular contact between the left third nerve and posterior cerebral artery was demonstrated with magnetic resonance constructive interference in steady state imaging (figure e-1 on the Neurology ${ }^{\circledR}$ Web site at Neurology.org), and episodes were resolved with carbamazepine. Aside from presumed transient tonic contraction of the left inferior rectus, there was no evidence that other third-innervated muscles were involved.

When vascular compression of an ocular motor nerve causes ocular neuromyotonia (ONM), it is thought that ephaptic transmission is responsible. Axonal "cross-talk" causes irritability and abnormal firing independent of the synapse. ${ }^{1}$ Without thin, heavily T2-weighted constructive interference in steady state or FIESTA (fast imaging employing steady-state acquisition) sequences, neurovascular contact can be missed. ${ }^{2}$ ONM has also been associated with radiation therapy, thyroid eye disease, mass lesions, or superior oblique myokymia. ${ }^{1}$ If diplopia manifests or worsens after prolonged eccentric gaze, ONM should be considered.

\section{STUDY FUNDING}

No targeted funding reported.

\section{DISCLOSURE}

D. Gold is co-section editor for Current Treatment Options in Neurology. Go to Neurology.org for full disclosures.

\section{REFERENCES}

1. Roper-Hall G, Chung SM, Cruz OA. Ocular neuromyotonia: differential diagnosis and treatment. Strabismus 2013; 21:131-136.

2. Cruz FM, Blitz AM, Subramanian PS. Partial third nerve palsy and ocular neuromyotonia from displacement of posterior communicating artery detected by high-resolution MRI. J Neuroophthalmol 2013;33:263-265. 


\title{
Neurology
}

\author{
Teaching NeuroImages: Ocular neuromyotonia: An underrecognized cause of transient \\ diplopia \\ Daniel R. Gold \\ Neurology 2016;86;e249 \\ DOI 10.1212/WNL.0000000000002725
}

\section{This information is current as of June 13, 2016}

\section{Updated Information \& Services \\ Supplementary Material}

\section{References}

Subspecialty Collections

\section{Permissions \& Licensing}

Reprints including high resolution figures, can be found at: http://n.neurology.org/content/86/24/e249.full

Supplementary material can be found at: http://n.neurology.org/content/suppl/2016/06/11/WNL.0000000000002 725.DC1

http://n.neurology.org/content/suppl/2016/06/11/WNL.0000000000002 725.DC2

This article cites 2 articles, 0 of which you can access for free at: http://n.neurology.org/content/86/24/e249.full\#ref-list-1

This article, along with others on similar topics, appears in the following collection(s):

All Neuro-ophthalmology

http://n.neurology.org/cgi/collection/all_neuroophthalmology

Diplopia (double vision)

http://n.neurology.org/cgi/collection/diplopia_double_vision

Ocular motility

http://n.neurology.org/cgi/collection/ocular_motility

Information about reproducing this article in parts (figures,tables) or in its entirety can be found online at:

http://www.neurology.org/about/about_the_journal\#permissions

Information about ordering reprints can be found online:

http://n.neurology.org/subscribers/advertise

Neurology ${ }^{\circledR}$ is the official journal of the American Academy of Neurology. Published continuously since 1951, it is now a weekly with 48 issues per year. Copyright (O 2016 American Academy of Neurology. All rights reserved. Print ISSN: 0028-3878. Online ISSN: 1526-632X.

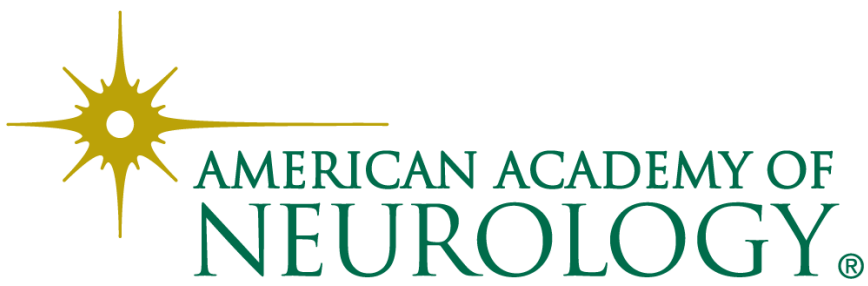

